\title{
Lateral
}

Journal of the Cultural Studies Association

\section{Political Blackness, British Cinema, and the Queer Politics of Memory}

\begin{abstract}
by Ashvin Kini I Articles, Issue 9.2 (Fall 2020)
ABSTRACT This essay queries "political Blackness" as a coalitional antiracist politics in England in the 1970s and 1980s. Contemporary debates on the relevance of political Blackness in contemporary British race politics often forget significant critiques of the concept articulated by feminist and queer scholars, activists and cultural producers. Through close readings of Isaac Julien and Maureen Blackwood's The Passion of Remembrance and Hanif Kureishi's Sammy and Rosie Get Laid, this essay examines cinematic engagements with political Blackness by foregrounding the gender and sexual fault lines through which queers and feminists articulated relational solidarities attentive to difference.
\end{abstract}

KEYWORDS Blackness, cinema, diaspora, feminism, $\underline{\text { Great Britain, queer, racism }}$

The mass mobilizations in response to the police murders of George Floyd and Breonna Taylor have been accompanied by calls for solidarity with Black communities in the global struggle against anti-Blackness. Activists Thenmozhi Soundararajan and Sharmin Hossain of Equality Labs, for example, have written powerfully about the necessity of diasporic South Asian communities critically reflecting on our own complicities in anti-Blackness, including through the logics of casteism: "We are part of an ecosystem of complicity that allows for our individual privileges as non-Black people of color to be weaponized for further criminalization of Black people."1 - At the same time there have also been renewed calls to problematize terms such as "people of color" in the US and "Black, Asian, and minority ethnic" (BAME) in the UK for the ways that such terms can homogenize and conflate non-white experiences, often at the expense of Black communities. $\frac{2}{2}$

Afropessimist scholar Jared Sexton, for example, has theorized what he calls "people-ofcolor-blindness": "a form of colorblindness... [that] misunderstands the specificity of antiblackness and presumes or insists upon the monolithic character of victimization under white supremacy." 3 In order to contextualize these debates I return to an earlier historical instance where calls for Black-Asian solidarity were being articulated and contested, specifically the debates around "political Blackness" in the UK context.

In the late 1960s and early 1970s, political Blackness emerged as a coalitional identity and praxis adopted by working-class Caribbean, African and South Asian migrants living in the United Kingdom. Rather than a sign of racial identity, political Blackness brought together various migrant racial and ethnic groups under a political identity based on their shared experience of British racism and the legacy of colonization. The strategic cross-racial and cross-ethnic coalitions engendered under the signifier "Black" worked against colonial policies of divide-and-rule that maintained white supremacy both in the former colonies and in the postcolonial metropole. As Stuart Hall has described it: "'Black' was made visible in its functioning as a discursive-political identity, a badge of identification adopted 
by different cultural groups in their struggle against racism, in place of an ethnic signifier referring to the content of distinct cultural differences." 4 - This adoption of Black as a political identity was thus framed as a way to create and sustain coalitional political communities through an emphasis on shared experience and social location within a racialized system of power. While contemporary critiques of political Blackness have rightly focused on its limitations as an identity rooted in a politics of racial equivalence, important critiques of political Blackness articulated by feminists and queers in the 1980s itself problematized any easy notion of solidarity based on shared experience. In conversation with US Black and women of color feminisms, queer feminist critiques of political Blackness sought to revitalize the concept through an emphasis on intersectional and relational frameworks that centered the gender and sexual politics of race. While political Blackness as an organizing identity politics has, as Jafari S. Allen writes, "disintegrated," the debates and contestations engendered by the scholarly, activist and creative output of British Black and Asian feminists and queers during this period remain important for critical genealogies of Black queer studies, Black feminisms, transnational and women of color feminisms, and queer of color critique. $\frac{5}{-}$ Let me be clear: my purpose here is not to gaze back nostalgically at the historically specific formation of political Blackness in order to advocate for its recuperation for the present conjuncture. Rather I seek to highlight the vibrant queer and feminist engagements with and critiques of the concept in its historical moment in order to foreground the continued urgency of crafting political and critical frameworks attentive to the interlocking systems of white supremacy, racial capitalism, colonialism, and heteropatriarchy.

This essay queries cinematic articulations of political Blackness for queer and feminist antiracisms and anti-imperialisms. I read Maureen Blackwood and Isaac Julien's The Passion of Remembrance (1986) and Stephen Frears and Hanif Kureishi's Sammy and Rosie Get Laid (1987), two films that are dissimilar in terms of their aesthetic styles and narrative structures, but nonetheless key texts of 1980s British cinema. Both films in different ways engage with the feminist and queer cultural politics that were instrumental in reassessing the potentially reductive solidarities underwriting the concept of political Blackness. - Read together these films interrogate, to varying degrees, the residues of empire in both British racism and elite postcolonial nationalisms in the late twentieth century by foregrounding the gender and sexual fault lines through which queers and feminists articulated relational solidarities attentive to difference. Political Blackness functions in The Passion of Remembrance and Sammy and Rosie Get Laid in three overlapping ways. First, it is a "multi-accentual" queer feminist politics that draws on multiple, nonequivalent histories of gendered racialization in postcolonial Britain, London specifically. ${ }^{7}$ Second, political Blackness can be read as a mode of cinematic practice that queers the politics of racial representation. By violating dominant cinematic conventionsfrom the fragmenting of linear time and continuity to the unexpected intrusion of the ghostly - the films make legible (albeit unevenly) subjugated histories of racial and colonial violence, as well as the marginalization of women and queers of color in antiracist movements and cultural imaginaries. Finally, political Blackness in these films is a critical memory discourse, a multi-faceted haunting that makes visible the literal and metaphorical specters of the British empire. As Avery F. Gordon notes in her influential text Ghostly Matters: Haunting and the Sociological Imagination, "Haunting is one way in which abusive systems of power make themselves known and their impacts felt in everyday life, especially when they are supposedly over and done with... [Haunting] alters the experience of being in time, the way we separate the past, the present, and the future." - Indeed, as I discuss in more depth below, the films underscore the uneven legacies and residues of 
British colonialism in the present in order to reckon with persistence of imperial racial ideologies as well as the masculinism of anticolonial and antiracist nationalisms.

\section{Political Blackness and British Cinema}

In a recent op-ed in the New York Times, Kwame Anthony Appiah described the "Black" in political Blackness as an umbrella term capacious enough to include "minorities with family origins in Asia and the Middle East as well as in Africa and its diaspora." Appiah continues,

"That's not to say it was the sturdiest of umbrellas: It was never uncontested." ${ }^{\prime}$ Indeed, among those engaged in contestations over the meanings and uses, the possibilities and limitations of political Blackness, feminists and queer activists and cultural producers articulated powerful intersectional critiques of the concept that unsettled the ease with which the term was evoked in the service of reductive solidarities rooted in the homogeneity and equivalence of experience. This unsettling of political Blackness by queers and feminists both reimagined and reanimated the concept by centering gender and sexuality as foundational to processes of racialization.

Black British feminisms emerged in conversation with and were influenced by the work of US Black and women of color feminisms that were articulating models of solidarity and strategic political coalition that did not rely only on the recognition of similarity, but also on reckoning with difference. 10 More specifically, these Black and women of color feminist formations attended not only to patriarchal domination but more radically to patriarchy's co-constitution with white supremacy, capitalism, heteronormativity, and colonialism. By insisting on an analysis of intersecting and interlocking systems of oppression, feminist and queer conceptions of political Blackness constituted what Grace Kyungwon Hong has called a "comparative analytic of difference," allowing for an interrogation of the increasingly uneven distribution of power within and across communities of color. 11 While coalition and collectivity are conventionally articulated through the recognition of commonality-for example, identification through a shared history of violence or traumawomen of color feminisms and queer of color formations are broadly concerned with the formation of collectivity through difference. As Hong and Roderick Ferguson remind us, "The mobilization of difference by women of color feminism and queer of color critique was intended not to erase the differentials of power, value, and social death within and among groups...but to highlight such differentials and attempt to do the vexed work of forging a coalitional politics through these differences." 12 - As noted by numerous British feminists, including Julia Chinyere Oparah, Avtar Brah, Pratibha Parmar, Heidi Safia Mirza, and Nydia A. Swaby, the most dynamic articulations of political Blackness were those that refused to consolidate into a reified identity grounded only in the similarity of experience and shared history. 13 Political Blackness, these scholars argue, was best understood as a critical discourse rooted in a differentiated and capacious definition of Blackness, one that was subject to constant self-reflection, reevaluation and revision. 14 Julia Chinyere Oparah, for example,writes in her study of Black British feminist activism, "' [B]lackness is not the natural preserve of any set of actors. Neither is it likely to be embraced by all members of the diverse communities of African and Asian descent in Britain. However, this should not be a reason to give up on an inclusive definition of Blackness. Rather, it is its very oppositionality, its insistence on discussion and explanation, which makes 'Black' a useful sign." ${ }^{\prime 15}$ Rather than conceiving of political Blackness as a form of ethnic erasure, Oparah and other feminist scholars and activists referenced here insisted on using the concept as a strategic political framework with which to reckon with the differential workings of 
gendered racialization and colonialism across British Black and Asian immigrant communities in the face of the overwhelming whiteness that organized British national identity. 16

In addition to the feminist and queer work cited above, Stuart Hall's classic essay "New Ethnicities" is foundational to my readings of The Passion of Remembrance and Sammy and Rosie Get Laid for his discussion of the shifts in Black British cultural politics in the context of emerging cinematic practices. Originally published in 1989, Hall's essay narrates the historical emergence of two phases or modes of Black British cultural politics that he argues were in dialectical tension with each other in the 1980s. The first is the coining of "Black" as a political identity of cross-racial solidarity based on the shared experience of British racism, despite the not insignificant differences of history, tradition and ethnicity. "'The Black experience," Hall argues, "as a singular and unifying framework based on the building up of identity across ethnic and cultural difference, became 'hegemonic' over other ethnic/racial identities-though the latter, of course, did not disappear."17 Black communities were positioned at the margins of representation, as the "unspoken and invisible 'other' of predominantly white aesthetic and cultural discourses." 18 The cultural politics of this "singular and unifying" mode of British Blackness intervened in the cultural arena by fighting not only for access to representation, but also by producing "positive" images to counter anti-Black negative stereotypes, to alter what Hall refers to as the "relations of representation." With few existing representations of British Blackness, it became the burden of Black cultural producers to speak for rather than speak from their communities. 19

At the same time, Hall observes that another mode of Black British cultural politics was emerging that sought to move from a "struggle over the relations of representation to a politics of representation itself." 20 This emergent cultural discourse was marked by what Hall famously termed, echoing the work of Black feminists, "'the end of innocence,' or the end of the innocent notion of the essential Black subject," in which the singular category of race is unsettled to reveal its complex interminglings, crossings and intersections with other structures of power. 21 A Black British cultural politics that proceeds from an understanding of the contingency of identities and communities within particular historical conjunctures thus enables for Hall a more critical conception of solidarity, coalition and affiliation that "works with and through difference...[to] make common struggle and resistance possible without suppressing the real heterogeneity of interests and identities." 22 As I will demonstrate in my critical readings below, The Passion of Remembrance and Sammy and Rosie Get Laid fall within this second mode of Black cultural politics in that they both work to displace the notion of a unified Black British subject by centralizing gender and sexuality as co-constitutive structures of power with race, while also displacing hegemonic modes of representation in their search for new ways of narrating the complexities and contradictions of British racial formations.

Finally, Hall demonstrates that the emergent Black British cultural politics must be understood as a diaspora politics. If the dominant tendency in diaspora studies has been to assert that diasporic subject and community formations are produced primarily through the negotiation of material and affective relations to a lost homeland, Hall shifts his gaze to ask how diasporic communities are positioned within the societies they come to inhabit once they have left the homeland behind. In the context of Black British filmmaking in the 1980s, Hall writes, 
In the case of the young Black British films and film-makers under discussion, the diaspora experience is certainly profoundly fed and nourished by, for example, the emergence of Third World Cinema; by the African experience; the connection with Afro-Caribbean experience; and the deep inheritance of complex systems of representation and aesthetic traditions from Asian and African culture. But, in spite of these rich cultural "roots," the new cultural politics is operating on new and quite distinct ground-specifically, contestations over what it means to be British. $\underline{23}$

Importantly, Hall locates the site of diasporic culture and critique not only in the complex relationship to a homeland of the past, but also in the "new and quite distinct" context of a diasporic present. Invoking Paul Gilroy's influential work, Hall goes on to say, "Fifteen years ago we didn't care, or at least I didn't care, whether there was any black in the Union Jack. Now not only do we care, we must." $\underline{24}$ As articulated in his emphatic must, diaspora is in this context fundamentally an intersectional racial analytic, mobilized to problematize and contest the inherent whiteness of British national identity as it is rooted in histories of British colonialism and slavery. Importantly, this call for a more capacious definition of Britishness is not an assimilationist project. If assimilation is defined through a temporal logic of inclusion where racialized migrants shed their past histories, cultures, languages, customs, and community formations to align themselves with a future-oriented white British modernity, Hall's insistence that one must care whether there is any Black in the Union Jack forces us to reckon with the stubborn persistence of the past as it impinges on the present and future, a thematic strain that runs through both The Passion of Remembrance and Sammy and Rosie Get Laid, to which I now turn.

\section{"Who Will Hear Me Now as I Remember, and Talk of Remembering?": The Passion of Remembrance}

Maureen Blackwood and Isaac Julien's The Passion of Remembrance was released in 1987 from the Sankofa Film and Video Collective. Sankofa was one of a number of Black film and video workshop collectives that were funded by the Greater London Council and Channel 4 in the aftermath of antiracist rebellions that had occurred in Notting Hill and Brixton in the late 1970s and early 1980s. These workshop collectives, which included John Akomfrah's Black Audio Film Collective, Ceddo Film and Video Workshop, and Retake Film and Video Workshop, were integral in the development of Black British independent film. Within these various workshops, young, mostly second generation Black British filmmakers staged important interventions in the politics of Black cinematic representation. Hamid Naficy observes that the workshops, though distinct from each other, shared some common thematic and political concerns: "Driven by the politics and poetics of decolonization, postcolonial diasporism, and critical theory, the workshops...questioned not only the mainstream media's stereotyping and misrepresentation on the black and subaltern subjects but also representation itself." ${ }^{2} \underline{5}$ In regard to the latter issue, Black film and video collectives often experimented with form as a way to deconstruct and problematize modes of cinematic representation and address that structured both mainstream commercial narrative cinema as well as documentary realism, particularly as it functioned as a mode of colonial knowledge in producing the visual repertoire of the racialized, colonized "Other." 26 Sankofa set itself apart from many of the other workshops 
in its focus on the intersection of race and colonialism with discourses of gender and sexuality. As Isaac Julien himself put it, "Sankofa consists of three Black women and myself, a Black gay man. Although there are workshops that have women and gay members, these issues have been a central political starting point for us." $\underline{27}$

The Passion of Remembrance is a multilayered text comprised of three separate but interwoven strands. First, there is the esoteric "Speaker's Drama" which features monologues and a conversation between an unnamed Black woman and Black man. These figures speak directly to the camera in talking head style interviews in which they remember and narrate their experiences of British racism and their involvement in antiracist struggles. The Black woman is a key figure in the film and throughout the Speaker's Drama she consistently calls into the question the gendered exclusions and oversights of the Black man's political philosophy, especially in the more confrontational scenes that occur in the film's second half. The second layer of the film is a more straightforward domestic narrative centered on Maggie Baptiste, a young aspiring filmmaker who lives with her brother, Tony, and her parents, Benjy and Gloria, immigrants from Saint Lucia. Maggie's friends Louise, Gary, and Michael (who are a couple) are also close with the family. Depicting the multi-generational Baptiste family allows the film to explore gender, sexual, and generational differences in relation to British racism and Black cultural politics. The conflicts between the various characters in the Baptiste family, as well as the man and woman of the Speaker's Drama, are reflective of how The Passion of Remembrance views Blackness not as a reified, coherent or stable identity, but rather as a site of continual contestation. The final layer of the film is comprised of archival documentary footage of protests and demonstrations in the 1970s and 1980s. This footage, edited together and presented as Maggie's experimental film work, also functions as a film within the film-the audience watches Maggie's documentary along with the characters. In shifting back and forth between these three strands, violating cinematic codes of linear temporality and narrative causality, The Passion of Remembrance suggests that Black subjectivities and politics are constituted not through a linear, developmental logic, but rather by the dynamic interaction of discursive and representational forms, between history and memory, past, and present.

The opening montage of the film depicts groups of Black and South Asian women participating together in protests and demonstrations-standing on picket lines in the rain, holding signs, distributing leaflets and pamphlets, marching in the streets with their fists in the air, laughing and smiling and shouting together. Soft, reflective music plays over these images, which are sometimes interrupted by the figure of Angela Davis speaking at a podium, attesting to the influence of US Black feminisms on Black British feminisms. These very first images in the film centralize the participation and involvement of Black women and women of color at the frontlines of antiracist political struggles. This montage bleeds into the first monologue of the Speaker's Drama, in which the woman speaker recounts her memories of her gendered experiences organizing against the racism of the 1970s:

Listening to the brothers, to their needs, wants. All the time listening, as they spoke, talked, demanded their right to be men. Then concentrating on how to rebuild them into men, fashioned into an image of their own choosing. Helping them, supporting them by always being there. Making the tea, coffee, curry, patties. Organizing the benefits, licking the stamps. Trying never to refuse. Later on having babies, running the home, whilst taking care of everything. Feeling tired at the beginning of the day... It was always important to be on the scene...Being an active conscious sister. Fashioned in an image designed for, but not by her. 
In this opening monologue the woman speaker narrates the extent to which Black women were simultaneously active agents in organized political protest but also often sidelined to carry out the devalued reproductive labor that sustains protest-listening, supporting and "rebuilding" the men, caring for the children, cooking the food, managing the domestic space, and providing administrative support ("organizing the benefits, licking the stamps"). According to the speaker, women were relegated to the role of supporter, listener, and caregiver, their attention and participation focused on addressing the needs and wants of men but never their own interests as Black women. "Being a conscious active sister" was an externally defined positionality, "designed for, but not by her." As this monologue demonstrates, the revolutionary subject of 1970s British antiracist political struggles is gendered male, with the woman never having the opportunity to articulate a revolutionary subjectivity on her own terms. The monologue thus operates on two levels. First, by describing the ways in which Black women's labor has historically been devalued by male leaders of antiracist struggles the monologue offers a pointed critique of the masculinism of antiracist organizing, thereby insisting on an understanding of racism as one vector of power that is differentially experienced with regard to gender. Second, the monologue also opens up a space in which to articulate a Black feminist politics that is not only critical of the history Black nationalism but more importantly also generative of other kinds of future-oriented political subjectivities, identities, and movements rooted in an intersectional analysis of power within struggles for justice.

This sense of critically reflecting on the past in order to formulate new kinds of political identities and movements for the future is the central theme of the narrative sections of the film, which focus on the domestic drama of the Baptise family. The family functions in multiple ways in the film. On the one hand, the family is a site of care, comfort, and support in the face of the racial and class stratifications of British society. Indeed, the film's introduction of the Baptiste family as they watch a game show on television is one of incredible warmth. At the same time, the family and the space of the home is also a site of conflict in which the diversity of Black experiences are represented and negotiated, especially in terms of gender, sexual, and generational difference. The film is careful not to present the generational and gender conflicts of the Baptise family in static terms. Affiliations between the various characters cut across gender and generation at different moments, creating a network of shifting affinities that do not easily resolve themselves in the binary oppositions of parent versus child, man versus woman, brother versus sister. This aspect of the narrative sections of the film thus provides a useful counterpoint to the Speaker's Drama, which runs the risk of homogenizing the experiences of Black communities in the binary opposition between the unnamed man and woman speakers. $\underline{28}$

The gendered differences in political viewpoint between Maggie and her elder brother Tony form one of the central conflicts in the Baptiste family and also help situate the debate between the man and woman in the Speaker's Drama within a specific context. For example, during a scene in which Maggie and her friends discuss the particularity of Black queer experiences, Tony is quick to accuse them of diluting their minds with the "white informed" issues of gender and sexuality. For Tony, as for the man in the Speaker's Drama, Blackness and Black politics are hindered when the experiences of Black women and Black queers are articulated in their specificity; conversations about gender and sexuality direct attention away from the "real" politics of race. As Tony says to Maggie, "You and I should be defining our own perspectives. Things should be informed by us for us." Channeling the woman in the Speaker's Drama, Maggie replies, "'By us for us!' That's the ideal, but the ideal's not what's happening is it? What's happening is you informing us. It's your perspectives that you want to inform us about. You're not really hearing anyone else...At 
the end of the day it's about how you define things because you've got the power." Like the woman in the Speaker's Drama, Maggie's critical posture toward Tony performs the dual function of intervening in the political imaginary of the past by pointing to the gendered distribution of power within antiracist struggles while also gesturing to other models of affiliation grounded in a multivalent analysis of race, gender, and sexuality.

Thus far my discussion of The Passion of Remembrance has focused on the queer feminist interventions it makes at the level of character and narrative. While these aspects of the film are undoubtedly compelling, they are all the more significant when considered alongside the film's brilliant experiments with cinematic form. In an interview with Richard Fung, Isaac Julien elaborates on Sankofa's commitment to experimenting with form as the means to both critique and generate new modes of cinematic representation: "We came to the conclusion that if we were to start negotiating our identities within the cinema that we'd have to somehow start to negotiate a film language that would actually try not to reproduce dominant ideology but would reproduce our desires and our politics. We also wanted there to be a politics of representation within the work that we produced." 29 As stated above, the three layers of The Passion of Remembrance-the Speaker's Drama, the Baptiste family narrative, and Maggie's documentary montages-are not presented in isolation. The film repeatedly shifts between them, violating the rules of continuity, linearity, and narrative. Each element of the film interconnects with another and there are moments where they seem to bleed into each other. For example, during a particularly tense moment in Maggie and Tony's final argument an abrupt jump cut takes the viewer back to the Speaker's Drama. The conversation continues as if uninterrupted with the unnamed woman taking over where Maggie left off. This strategy is mirrored in the formal structure of Maggie's experimental films as well, which are arguably the centerpiece of The Passion of Remembrance. As Maggie describes them to her friends-and the viewer - "What we're going to be witnessing is archival footage of demonstrations, festivals, things like that. I've edited them all together to form a montage of images of protest and celebration of solidarity." The montages themselves, such as the one described above that opens the film, present footage from a vast array of movements, including protests for worker's rights, queer liberation, racial justice, and women's rights. As the camera lingers on the faces and bodies of the protesters what emerges is a moving celebration of the spirit and labor of social justice movements and activists. Yet in the suturing together of what Tony and the man in the Speaker's Drama see as separate issues of labor, gender, sexuality, and race, Maggie's filmmaking practice insists on seeing continuity and overlap between these issues and the movements they inspire. In her films, Maggie is engaged in the complex work of trying to articulate what Julien refers to as a film language, a politics of representation that can encompass the specificity of struggles of racial, gender, class, and sexual justice while also attending to the convergences between them.

Maggie is thus engaged in the work of "queer curation," which Gayatri Gopinath has recently defined as a project of care-taking —of caring forand caring about the past with the "obligation to impart that 'caring about' to others." 30 In the selection and juxtaposition of images, sounds, and effects that make up her montages, Maggie is making connections in and through difference, moving between past and present, and in the process imparting the significance of those connections to her viewers - both to the viewers in the film and to us, the viewers of The Passion of Remembrance. As Maggie's friends watch, discuss and debate her films, the viewer is also invited into the conversation by having to think through the complexities of the distinct but imbricated histories of powerful resistance to British empire and white supremacist heteropatriarchy that Maggie has so carefully presented to us. What we are left with at the end of The Passion of Remembrance is not only a narrative 
dramatization of the ways in which Black women and queers have been marginalized in antiracist struggles, but also a critical conversation about the necessity of building alliances across difference in order to construct alternative political imaginaries and worlds. Maggie's documentary montages, and indeed, The Passion of Remembrance itself, can be read as a cinematic act of queer re-membering. By "re-membering" I am not referring to the project of recuperating and restoring that which was once whole. Rather, the queerness of Maggie's curatorial filmmaking practice resides in her careful assembly of discarded, devalued, and forgotten fragments of memory, stitching them together not in the service of nostalgic reminiscences of what once was, but rather as critical imaginings of other kinds of relationalities that might yet come into being.

\section{Empire's Black Queer Hauntings: Sammy and Rosie Get Laid}

Like The Passion of Remembrance, Stephen Frears and Hanif Kureishi's Sammy and Rosie Get Laid critically explores the past as it bears upon the present. However, it is different from Passion in important ways. Passion focuses primarily on the internal gender and sexual dynamics of Black British communities in order to displace the notion of a unified Black radical subject, which was mirrored in the film's non-linear, fragmented visual and narrative style. Sammy and Rosie is less formally experimental in the sense that it stays within the realm of fictional narrative, although the introduction of the supernatural in the film's final act departs from the conventions of cinematic realism. Through its depiction of the racial and gender diversity of postcolonial London, Sammy and Rosie Get Laid mobilizes tropes of memory and haunting to trace the continuities between British colonialism and contemporary processes of differential racialization and also to critique the violences of elite postcolonial nationalisms.

Sammy and Rosie Get Laid was released to both acclaim and controversy in 1987. This second collaboration between filmmaker Stephen Frears and screenwriter Hanif Kureishi (after their acclaimed 1985 film My Beautiful Laundrette) continues their engagement with the racial and sexual politics of Thatcher-era England. $\frac{32}{\text { Unlike Laundrette, whose }}$ narrative focused primarily on the queer romance between an upwardly mobile British Asian man and a working-class former member of the National Front, Sammy and Rosie Get Laid employs a much broader and in some ways less forgiving canvas. The world of Sammy and Rosie Get Laid is populated by an array of characters from different racial, gender and class positions, offering a kind of cross-section of postcolonial London that, at least initially, refuses to privilege one character or narrative over another. $\frac{33}{\text { Sammy, a }}$ British Pakistani accountant, and Rosie, a white social worker, are a polyamorous married couple. Rosie enjoys the sexual freedom afforded by this arrangement, telling Sammy, "Freedom plus commitment. Those were our words. They were to be the pillars of our love and life together." Sammy also pursues other sexual partners, most notably Anna, a white American photographer, but his jealousy and insecurity often get the best of him. Sammy's father, Rafi Rahman, arrives in London from Pakistan. An anticolonial nationalist in his youth, Rafi studied in London before returning to the subcontinent to take a position in the postcolonial Pakistani government. He has returned now to London in order to escape persecution in Pakistan for political corruption and violence. In London he rekindles an affair with Alice, a white British woman with whom he had been in love while he was a student. While Rosie initially welcomes Rafi into their home, Sammy's resentment of his 
father's desertion of him as a child weighs heavily on their relationship. Rafi befriends a young Black man named Danny, who eventually becomes Rosie's lover. Added to the mix are Rani and Vivia, a South Asian and Black lesbian couple who are close friends of Rosie's. Rani and Vivia work for a leftist political newspaper and uncover information about Rafi's involvement in the torture of political dissidents in Pakistan. Finally, in a turn to the supernatural, there is the unnamed ghostly taxi driver who we initially see driving Rafi from the airport. This ghost, a material manifestation of Rafi's torture victims, appears frequently in the background action in the second half of the film before ultimately seeking his revenge on Rafi, leading Rafi to commit suicide.

As the above description demonstrates, it is difficult to articulate a central plot line for the film. Instead, Frears and Kureishi explore the myriad encounters and relationships between the characters in order to engage an almost endless list of thematic concerns: the racial and class dispossessions engendered by Thatcherism, the legacies of empire in London in the late twentieth century, the limits of liberal multiculturalism, police harassment and violence directed at British Black communities and communities of color, postcolonial state violence and torture, anticolonial and anti-imperial resistance, the dynamic articulation of postcolonial identities, and alternatives to normative heteropatriarchy, especially those embodied and practiced by diasporic queers of color. As Ranita Chatterjee suggests, the "complexity of representation" found in Sammy and Rosie stems from its displacement of white heterosexual masculinity: "The absence of the traditional white heterosexual male as implied center liberates the conceivable play of images on the screen, thus enabling a veritable explosion of difference." 34 Like Chatterjee, I am particularly interested in the political possibilities made available through the secondary characters of Danny, Rani and Vivia, and also the ghostly taxi driver. Collectively these characters not only point to modes of critique that shape the film's critical posture toward Sammy and Rosie's liberalism and Rafi's heteropatriarchal nationalism, but they also enable a reckoning with the legacies of colonial and postcolonial violence in late twentieth-century London, although as I note below that reckoning has significant limits.

From the start, Sammy and Rosie Get Laid is invested in drawing continuities between the history of British colonialism and the position of working-class communities of color in London in the 1980s. The film opens with the image of a desolate urban wasteland under a highway overpass. Played over this image, which precedes the opening credits of the film, is the voice of Margaret Thatcher giving her victory address on the night of the 1987 election. "We have a great deal of work to do so no one must slack," she says to an audibly joyful, laughing audience, "You will have a marvelous party tonight, and you can clear up tomorrow. But on Monday, you know we've got a big job to do in some of those inner cities." This establishing shot of the barren overpass actually references the end of film after a community of unhoused people has been forcibly removed from the land in order for a property developer to build on it. After this brief opening scene and the main credits, we witness the brutal murder of an unnamed Black woman by the police while they search

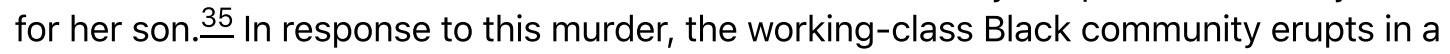
rebellion. Police in full riot gear are called in as fires rage outside Sammy and Rosie's apartment window on the day that Rafi arrives from Pakistan. In the pairing of these two opening scenes-one depicting the aftermath of the displacement of the urban poor in service of neoliberal capitalist development, the other powerfully representing the surveillance and susceptibility of diasporic Black working class communities to statesanctioned violence and death-the film yokes together the intersecting structures of race, class, and gender as the terms of what Danny will later refer to as "domestic 
colonialism," which he sees as the condition of working-class immigrant communities of color in London. $\underline{36}$

Indeed, the film is replete with signs of the colonial past reappearing in the postcolonial present: the "anticolonial stones" wielded by Rafi is his youth, which find their present day counterpart in the bricks thrown by participants of the rebellion; Alice's taste for Earl Grey tea and Jamaica rum cake, and her dusty childhood photos of herself with her Indian ayah; Danny's questions to Rafi- "You guys ended colonialism non-violently. You'd sit down all over the place, right?"-as he considers different resistance strategies. Sammy and Rosie Get Laid is thus particularly attentive to the ways in which the lifespan of empire exceeds any notion of linear progress from the colonial to the postcolonial. Instead, as the above examples attest, the film ruminates on the ongoing, residual effects of colonial power relations in the racial and cultural formations of late-twentieth century Britain. $\frac{37}{}$ Danny is a particularly suggestive figure here, as he comes to embody a playful, queer critical posture toward these colonial remnants. Danny is a ubiquitous but subtle presence in the film, often seen in the background of the action. He is one of the first characters to whom the audience is introduced and functions as a familiar though somewhat elusive anchor for the audience as the film moves between its various storylines. When he meets Rafi for the first time, he introduces himself as Danny and quickly adds, "But people who like me call me Victoria," ironically and queerly invoking the monarch most associated with Britain's colonial expansion. Danny's Victoria persona is evoked again a few scenes later when he is introduced to Alice as he dons her lace and feather covered gardening hat which he finds discarded outside her suburban home. This invocation of Queen Victoria in the figure of Danny, a working-class Black British youth, simultaneously acknowledges, on the one hand, the imperial history that would bring Black and Asian laboring subjects to the colonial metropole in the post-war period, and on the other hand the mobilization of working-class communities of color in critically challenging and reimagining the very notion of British national identity in the decades after the formal end of empire.

If Danny/Victoria is suggestive of a queer challenge to the colonial history of Britain, Rani and Vivia, the interracial Black and South Asian lesbian activist couple, can be read as the figureheads of the film's queer diasporic engagement with the gendered violences of postcolonial nationalism as represented by Rafi. 38 While in their initial scenes it appears as if Rani and Vivia will simply be used to humorously undercut Rafi's discomfort with (queer) women's sexuality, it is soon revealed they are in fact the catalyst for the film's engagement with Rafi's overseeing of state torture programs in Pakistan. $\frac{39}{}$ When he first arrives in Sammy and Rosie's apartment, Rani takes Rosie aside to ask if she is aware of exactly who Rafi is and what his role was in the postcolonial Pakistani government. Rosie admits to not knowing much about Rafi's political career and Rani promises that she will "dig out some stuff about him." Later, we see Rani and Vivia at the offices of what seems to be a nonprofit organization, described in the screenplay as "rather like Amnesty." 40 An East Asian woman retrieves the multivolume file on Rafi and gives it to Rani and Vivia, who affectionately hold hands with each other at her desk. In this moment of queer intimacy in the Amnesty office and the collective uncovering of Rafi's crimes by three politicized women of color, we can observe the linking of Rani and Vivia's queer sexuality to their pursuit of information about Rafi's political career, a linkage which will come to fruition in Rani's brilliant final confrontation with Rafi towards the end of the film.

After spending the night with Alice, Rafi returns to Sammy and Rosie's apartment only to find Rani and Vivia in bed together. He and Rani exchange insults in Urdu and Punjabi as 
she chases him first out the bedroom then the apartment. This is the only scene in the movie not performed in English and it is subtitled as follows:

RAFI: What are you doing? You perverted, half-sexed, God-accursed lesbians! God save my eyes from the sights I'm seeing!

RANI: Fuck off, you old bastard! I'll tin-opener off your foreskin! I'll shove live rats up your camel! Who the fuck do you think you are! Pigshit bastard! I'll crush his balls!

Let me get at that withered sperm-factory!

As Rahul Gairola astutely argues, the "official" translation offered by the subtitles omits crucial content from Rani's curses, specifically her repeated references to Rafi as a "bloody criminal" and "bloody crook." $\underline{41}$ The inaccurate subtitling of the Urdu and Punjabi insults during this scene has led viewers (and some critics) to read this scene only as a comedic representation of Rani as a hysterical lesbian wielding a piece of wood with the intention of beating Rafi. Gairola complicates this reading when he writes:

While subtitled phrases like "perverted, half-sexed, God-accursed lesbians" and "I'll shove live rats up your camel" offer creative pejoratives that sound funny...they do a disservice to the political urgency of what is actually said in the Urdu exchange. The political significance of what would normally be a rather humorous scene is undermined by the elision of the accusation and repetition by Rani that Rafi is a "criminal." $\underline{42}$

At this point in the film, Sammy and Rosie are fully aware of the extent of Rafi's crimesRani had indeed passed along the file about him. Rosie is outraged by what she learns but nonetheless proves to be ineffective in confronting Rafi. Her politics are ultimately, as Rani points out, "just surface...liberalism gone mad." 43

The conflict between Rafi and Rani described above is remarkable as well because it directs the film into its final act, in which Rafi will be forced to come face to face with the literal ghosts of his past. On the street just after escaping Rani, Rafi notices an elderly South Asian man wearing an eye patch and a large bandage on his head staring at him. This man had been his taxi driver earlier in the film and as Rafi watches him pass the man evaporates into thin air. For the rest of the film this ghost follows Rafi everywhere he goes though no one else is able to see him. In introducing the ghost just after the confrontation in which Rani repeatedly calls Rafi a criminal, a link is made between Rani and the ghost, establishing a connection between these two figures who come to facilitate the film's full engagement with the violence upon which Rafi's nationalism rests. As Gayatri Spivak argues, Rani and Vivia form the basis of the film's turning away from realism through the introduction of the supernatural and the ghostly: "It's because of [Rani and Vivia's] factfinding that the film can utilize...non-realistic techniques...[such as] the ghost figure. The film justifies its move away from realism, its stylistic transformation in terms of these two lesbians which I find quite interesting." 44 The linking of Rani and Vivia to the ghost can be read as a kind of queer affiliation. $\frac{45}{}$ While unable to see the ghostly presence, they have "made common cause" with the ghost, to use Avery Gordon's phrasing. $\frac{46}{\text { Neither }}$ intentional nor conscious on their part, this affiliation between Rani and Vivia and the ghost nonetheless enables the film, as Spivak suggests, to manipulate the stylistic conventions of realism, allowing the ghost to materialize, to speak, and ultimately to act on Rafi and the violent histories he carries with him. 
The final encounter between Rafi and the ghost occurs in Danny's trailer, which is parked on the barren wasteland of the film's opening on the night before the eviction that will eventually displace the community of people who live there. Distraught over his failed love affair with Alice and the increasingly tense environment at Sammy and Rosie's apartment, Rafi is visibly agitated when the ghost appears in the dark caravan. The ghost is naked now and though his body is partially shrouded in shadow his figure reveals to the audience the extent of his injuries: his body is covered with bloody bruises and burns; his left eye is missing from its socket and he wears a metal headpiece used in electroconvulsive torture. He slowly begins to remove the electrodes stuck onto his body and places the electroconvulsive apparatus on Rafi's head. Rafi pleads for forgiveness and tries to justify his past crimes: "The country needed a sense of direction, of identity. People like you, organizing into unions, discouraged and disrupted all progress." As the embodiment of the elite postcolonial nationalism of the immediate post-independence moment, Rafi's dialogue is an almost perfect instantiation of what Frantz Fanon in The Wretched of the Earth called the "pitfalls of national consciousness," in which the authority of the departing colonial power is transferred to the elite nationalist bourgeoisie at the expense of poor, working-class, and marginalized peoples. 47 With the metal headpiece affixed to Rafi's head, the ghost begins to recede from view. The headpiece begins to glow with electricity. "All of human life you desecrated, Rafi Rahman!" yells the ghost, as Rafi screams in pain.

While this scene might be read as simply the final confrontation between two individual people-Rafi and the ghost of the tortured man-this scene has important social, rather than only individual import. While the physical manifestation of the ghost in the figure of the cab driver does indeed mark the film's explicit move into non-realist modes of representation, the haunting that the ghost literalizes has already been a "seething presence" in the film in the files of information about Rafi's involvement in torture. 48 The revelation of the contents of the files occurs earlier, as Rosie reads aloud to Sammy a testimonial transcribed from interviews with one of Rafi's victims. The testimony is utterly graphic in its depiction of sexual violation, drawing on the full repertoire of heteropatriarchal and homophobic anxieties about male submission, anal penetration and masculine vulnerability. Read alongside the earlier scenes of Rafi's discomfort with Rani and Vivia's sexuality, his investment in a heteronormative politics of reproduction and inheritance, his accusation that Rosie's resistance to having children makes her a "damned dyke," and Danny's queering of Queen Victoria, we can read the sexual as the primary terrain upon which Sammy and Rosie stakes its multivalent queer diasporic critique of postcolonial nationalism. In this sense, to read the literalization of the ghost and his final confrontation with Rafi simply as a matter of individual revenge would be to diminish the political stakes of this scene. Instead, following Avery Gordon, we can read the appearance and the agency of the ghost as evidence that he "is not simply a dead or missing person, but a social figure." 49 Thus, through Rani and Vivia's making common cause with the ghost, Sammy and Rosie Get Laid articulates a powerful queer diasporic critique of postcolonial nationalism and the persistence of colonial racial ideologies for South Asian migrants in Britain.

Yet, while the opening set-up of the film (again what Chatterjee calls "an explosion of difference") points to the possibility of a multivocal analysis of the racial, sexual, and class politics of the Thatcher era, the film ultimately privileges the subject positions of the South Asian characters over all others. As such, the film is much less effective in its depictions of both the specificity of white supremacist anti-Black violence that underlies the murder of the unnamed Black mother in the opening sequence as well as the ultimately rather flat characterization of Vivia. Although Rani and Vivia are initially positioned together as key 
agents of the film's intersectional critique of British gendered racisms, in the final confrontation with Rafi before the arrival of the ghost only Rani emerges as the singular figure of critique. Vivia remains in the background, her image and her voice virtually drowned out by the Rani and Rafi's curses at each other. Moreover, as Ranita Chatterjee notes, the shift to subtitled Urdu and Punjabi in this scene (again, the only scene in the film not in English) actually redraws the lines of similarity and difference between Rafi, Rani and Vivia: "What begins as Rafi's desire to mark Rani and Vivia as different, if not deviant, because of their sexual difference gets displaced by Rafi's sameness with Rani and her difference from her lesbian love, Vivia." 50 Thus, we might observe in this scene the breakdown of the film's celebratory depiction of the figure of the "interracial Black-Asian lesbian couple" as the very sign of its radical intersectional politics. Unfortunately, the film offers little in the way of understanding the substance of either Rani and Vivia's politics beyond their critique of Rafi or the racial and sexual dynamics of their relationship itself. Rani's confrontation with Rafi is indeed the catalyst for the final return of the ghostly taxi driver intent on redressing the brutalities of Rafi's postcolonial nationalism, but attending to the film's displacement of Vivia in this scene (and ultimately the rest of the film) reveals how quickly the "Black" of political Blackness can be crowded out by the brown. While the taxi driver is the only literal ghost in the film, Vivia might actually be its most powerful figure of haunting. Vivia remains an absent presence that marks the film's tacit acknowledgement of Black women's social location in Thatcher-era England as well as the Black and Asian feminist solidarities discussed above but without the necessarily robust engagement with the complexities and contradictions therein. Sammy and Rosie Get Laid asks that we follow multiple ghosts-the taxi driver and also Vivia-as they leads us "to that dense site where history and subjectivity make social life," where the past and present collide in order to unsettle. $\frac{51}{}$ Unfortunately, the film loses sight of Vivia along the way.

\section{Conclusion}

In my readings of The Passion of Remembrance and Sammy and Rosie Get Laid, I have attempted to highlight the critical work of political Blackness for imagining models of queer feminist affiliation with the potential to disrupt dominant social orders and modes of representation. I cannot help but be moved by Maggie Baptiste's curatorial filmmaking practice, her experiments with form and memory in her queer montages of Black-Asian feminist solidarities. At the same time, Sammy and Rosie Get Laid lays bare the potential pitfalls of solidarities that fail to adequately address asymmetries of power between and among differently racialized and gendered formations.

We are no longer in a moment when an identitarian framing of political Blackness is useful or even desirable, but the project of constructing critical frameworks and analytics that can attend to the multiplicity of oppressive forces that structure our lives remains as urgent as ever. Luckily, there is a vibrant history and vast archive of transnational Black and women of color and queer of color work from which we might draw. In addition to the work of British feminists and queers cited throughout this essay, we might reflect on the continued relevance of Cathy Cohen's foundational call to "search for those

interconnected sites of resistance from which we can wage broader political struggles."

Such a project might proceed from Lisa Lowe's visionary readings of the "intimacies of four continents" across colonial archives, histories and literatures. $\frac{53}{1 t}$ might look for what Grace Kyungwon Hong and Roderick Ferguson call "strange affinities" grounded in difference that women of color and queer of color formations make legible as alternatives 
to both dominant and minority nationalist framings of comparative racialization. $\frac{54}{\mathrm{We}}$ might engage the genealogies of what Vanita Reddy and Anantha Sudhakar have called "feminist and queer Afro-Asian formations," that disrupt the heteropatriarchal logics of dominant historiographic methods in Afro-Asian studies. $\frac{55}{}$ We might look to Thenmozhi Soundararajan and Sharmin Hossain, who I cited at the very beginning of this essay, for models of how to link the violences of anti-Blackness, caste apartheid and settler colonialism; and also to the recent collaborations between Black Women Radicals and the Asian American Feminist Collective that have explored the differential workings of antiBlackness and anti-Asian racism in the context of the Covid-19 pandemic. $\frac{56}{}$ Finally, we might follow Maggie Baptiste whose queer curatorial practice, her passion for remembrance, pieces together subjugated histories of queer alliance to forge new kinds of relation in the present and for the future.

\section{Acknowledgements}

Intellectual work is always a collective endeavor. I am lucky that so many wonderful and brilliant people have contributed to the thinking of this essay. I thank Lisa Lowe and Shelley Streeby always, for everything. Yumi Pak, Joo Ok Kim, and Victor Betts listened to my late night musings and offered invaluable feedback over email, text, phone, Zoom, and FaceTime. Much love. Thank you also to the editors and anonymous reviewers at Lateral for your generous feedback and to Women Make Movies for use of the still image from The Passion of Remembrance.

\section{Notes}

1. Thenmozhi Soundararajan and Sharmin Hossain, "South Asians for Black Lives: A Call for Action, Accountability and Introspection," Wear Your Voice Magazine, June 3, 2020, https://wearyourvoicemag.com/south-asians-for-black-lives-a-call-for-action/ < https://wearyourvoicemag.com/south-asians-for-black-lives-a-call-for-action/> . Equality Labs is an Ambedkarite South Asian progressive organization that works to combat caste apartheid, Islamophobia and white supremacy, https://www.equalitylabs.org < https://www.equalitylabs.org/> .

2. See for example E. Tammy Kim, "The Perils of 'People of Color,'" New Yorker, July 29, 2020, https://www.newyorker.com/news/annals-of-activism/the-perils-of-people-of-color < https://www.newyorker.com/news/annals-of-activism/the-perils-of-people-of-color> ; Shereen Marisol Meraji and Natalie Escobar, "Is it Time to Say R.I.P to 'POC'?" Code Switch, NPR, September 30, 2020, https://www.npr.org/2020/09/29/918418825/is-it-time-to-say-r-i-p-to-po-c < https://www.npr.org/2020/09/29/918418825/is-it-time-to-say-r-i-p-to-p-o-c>; and Nora Fakim and Cecilia Macaulay, "'Don't Call Me BAME': Why Some People are Rejecting the Term," BBC News, June 30, 2020, https://www.bbc.com/news/uk-53194376< https://www.bbc.com/news/uk-53194376>. ?

3. Jared Sexton, "People-of-Color-Blindness: Notes on the Afterlife of Slavery," Social Text 103, Vol. 28 , No. 2 (2010), 48. Frank B. Wilderson III has written extensively about what he calls the "ruse of analogy." See Wilderson's Red, White, and Black: Cinema and the Structure of U.S.

Antagonisms (Durham, Duke Univ. Press, 2010) and his recent memoir Afropessimism (New York: Liveright, 2020). See also Rinaldo Walcott, "The End of Diversity," Public Culture 31, No. 2 (2019): 393-408.

4. Stuart Hall, The Fateful Triangle: Race, Ethnicity, Nation, ed. by Kobena Mercer (Cambridge, Harvard Univ. Press, 2017), 94. D 
5. Jafari S. Allen, "Black/Queer/Diaspora at the Current Conjuncture," GLQ 18, No. 2-3 (2012): 216. For more on the import of women of color feminisms for genealogies of queer of color critique see Grace Kyungwon Hong and Roderick A. Ferguson, eds., Strange Affinities: The Gender and Sexual Politics of Comparative Racialization (Durham: Duke UP, 2011); Michael Hames-García, "Queer Theory Revisited," in Gay Latino Studies: A Reader, eds. Michael Hames-García and Ernesto Javier Martínez (Durham: Duke Univ. Press, 2011), 19-45; Roderick Ferguson, Aberrations in Black: Toward a Queer of Color Critique (Minneapolis: Univ. of Minnesota Press, 2004); and José Esteban Muñoz, Disidentifications: Queer of Color and the Performance of Politics (Minneapolis: Univ. of Minnesota Press, 1999).

6. The Passion of Remembrance, dir. Maureen Blackwood and Isaac Julien (1986, Sankofa Film and Video Collective), VHS; Sammy and Rosie Get Laid, dir. Stephen Frears, screenplay by Hanif Kureishi (1987, Cinecom Films), VHS.

7. Paul Gilroy's proposes an understanding of Blackness as a "multi-accentual sign" as a way to circumvent essentialist definitions. See Paul Gilroy, "Cruciality and the Frog's Perspective: An Agenda of the Difficulties for the Black Arts Movement in Britain" in Small Acts: Thoughts on the Politics of Black Cultures (London: Serpent's Tail, 1993).

8. Avery F. Gordon, Ghostly Matters: Haunting and the Sociological Imagination (Minneapolis: University of Minnesota Press, 1997), xvi. ?

9. Kwame Anthony Appiah, "What We Can Learn From the Rise and Fall of 'Political Blackness," New York Times, October 7, 2020, https://www.nytimes.com/2020/10/07/opinion/political-blacknessrace.html < https://www.nytimes.com/2020/10/07/opinion/political-blackness-race.html> . See also Reni Eddo-Lodge, About Race, "Political Blackness," podcast audio, April 11, 2018, https://www.aboutracepodcast.com/4-political-blackness < https://www.aboutracepodcast.com/4-political-blackness>.

10. For example see Pratibha Parmar, "Black Feminism: The Politics of Articulation," in Identity: Community, Culture, Difference, ed. Jonathan Rutherford (London: Lawrence and Wishart, 1990), which includes a beautiful interview conversation between Parmar and June Jordan. Parmar elaborated on transnational links between British and US Black feminisms in her film $A$ Place of Rage(1991, Women Make Movies), which features extended interviews with Jordan, Angela Davis, and Alice Walker. See also Hazel Carby, "White Woman Listen! Black Feminism and the Boundaries of Sisterhood" in The Empire Strikes Back: Race and Racism in Seventies Britain, Center for Contemporary Cultural Studies, University of Birmingham (London: Hutchinson, 1982), 212-235; and Valerie Amos and Pratibha Parmar, "Challenging Imperial Feminism," Feminist Review 17 (1984): 3-19.

11. Grace Kyungwon Hong, The Ruptures of American Capital: Women of Color Feminism and the Culture of Immigrant Labor (Minneapolis: Univ. of Minnesota Press, 2006). For foundational theorizations of intersectionality and interlocking systems of oppression see Kimberlé Crenshaw, "Mapping the Margins: Intersectionality, Identity Politics, and Violence Against Women of Color," Stanford Law Review 43, no. 7 (1991): 1241-1299; Patricia Hill Collins. Black Feminist Thought: Knowledge, Consciousness, and the Politics of Empowerment (New York: Routledge, 1990); and the Combahee River Collective, "A Black Feminist Statement" in The Black Feminist Reader, ed. Joy James and T. Denean Sharpley-Whiting (Malden: Blackwell, 2000), 261-70.

12. Hong and Ferguson, Strange Affinities, 9.

13. Julia Sudbury, Other Kinds of Dreams: Black Women's Organizations and the Politics of Transformation. (London: Routledge, 1998); Avtar Brah, Cartographies of Diaspora: Contesting Identities. (London: Routledge, 1996); Nydia A. Swaby, "Disparate in Voice, Sympathetic in Direction: Gendered Political Blackness and the Politics of Solidarity," Feminist Review 108 (2014): 11-25; Heidi Safia Mirza, ed., Black British Feminism: A Reader (London: Routledge, 1997).

14. Michelle Wright, although not writing only about the Black British context, has made a similar feminist critique of models of African diaspora studies defined through tropes of common history or culture. My suggestion that political Blackness is best understood as a critical discourse rather than an identity category is indebted to her significant work. See Michelle Wright, Becoming Black: Creating Identity in the African Diaspora (Durham: Duke University Press, 2004). 
15. Sudbury, Other Kinds of Dreams, 116.

16. For a brilliant and influential discussion of the ways in which dominant conceptions of post-war British national identity were rooted in whiteness, see Paul Gilroy's There Ain't No Black in the Union Jack, in which he writes, "The politics of 'race' in this country is fired by conceptions of national belonging and homogeneity which not only blur the distinction between 'race' and nation, but rely on that very ambiguity for their effect." Paul Gilroy, "There Ain't No Black in the Union Jack": The Cultural Politics of Race and Nation (Chicago: University of Chicago Press, 1987), 45.

17. Stuart Hall, "New Ethnicities," in Stuart Hall: Critical Dialogues in Cultural Studies, eds. KuanHsing Chen and David Morley (New York: Routledge, 1996): 442; A. Sivanandan, Ashley Dawson and Claire Alexander each provide useful genealogies of the emergence of this kind of Black British politics. See A. Sivanandan, "From Resistance to Rebellion: Asian and Afro-Caribbean Struggles in Britain" in A Different Hunger: Writings on Black Resistance (London: Pluto Press, 1991); Ashley Dawson, Mongrel Nation: Diasporic Culture and the Making of Postcolonial Britain (Ann Arbor, Univ. of Michigan Press, 2007); and Claire Alexander, "Breaking Black: The Death of Ethnic and Racial Studies in Britain," Ethnic and Racial Studies 41, no. 6 (2018).

18. Hall, "New Ethnicities," 442.

19. Hall, "New Ethnicities," 442. For an influential analysis of the "burden of representation" placed on minoritized cultural producers see Kobena Mercer, Welcome to the Jungle: New Positions in Black Cultural Studies (New York: Routledge, 1994).

20. Hall, "New Ethnicities," 444.

21. Hall, "New Ethnicities," 444.

22. Hall, "New Ethnicities," 445.

23. Hall, "New Ethnicities," 447.

24. Hall, "New Ethnicities," 448, emphasis in original.

25. Hamid Naficy, An Accented Cinema: Exilic and Diasporic Filmmaking (Princeton: Princeton University Press, 2001), 88. For illuminating interviews with members of Sankofa and the Black Audio Film collective see Coco Fusco, Young, British and Black: The Work of Sankofa and Black Audio Film Collective (Buffalo: Hallwalls/Contemporary Arts Center, 1988).

26. See Mercer, Welcome to the Jungle. ?

27. See Richard Fung, "Eyes on Black Britain: An Interview with Isaac Julien." Fuse 48 (Winter 1987/88): 25-28.

28. Kobena Mercer is quite critical of the Speaker's Drama in The Passion of Remembrance, arguing that these portions of the film are "profoundly monologic" rather than dialogic, homogenizing, and totalizing rather than differentiated; see Mercer, Welcome to the Jungle, 65.

29. Fung, "Eyes on Black Britain."

30. Gayatri Gopinath, Unruly Visions: The Aesthetic Practices of Queer Diaspora (Durham: Duke UP, 2018), 4 .

31. My thinking on queer memory here is indebted to Fatima El-Tayeb's beautiful theorization of queer memory discourses, which she argues are "not built on linear notions of roots and authentic origins, but on the grounding of a community embracing its 'inauthentic,' fractured nature rather than resolving it through a projected, unambiguous past." See Fatima ElTayeb, European Others: Queering Ethnicity in Postnational Europe (Minneapolis: Univ. of Minnesota Press, 2011), 43-44.

32. My Beautiful Laundrette, dir. Stephen Frears, screenplay by Hanif Kureishi (1985, Working Title Films), DVD. ? 
33. Gayatri Spivak argues that this shift in focus from the individual within a political context to a more collective representation might constitute a pattern for postcolonial cultural producers. See Gayatri Chakravorty Spivak, "In Praise of Sammy and Rosie Get Laid," Critical Quarterly 31, no. 2 (June 1989): 80-88.

34. Ranita Chatterjee, "An Explosion of Difference: The Margins of Perception in Sammy and Rosie Get Laid," in Between the Lines: South Asians and Postcoloniality, eds. Deepika Bahri and Mary Vasudeva (Philadelphia: Temple University Press, 1996): 172.

35. Both bell hooks and Rahul Gairola note that this scene was inspired by the real-life shooting of Dorothy "Cherry" Groce on September 28, 1985. Police raided Groce's Brixton home in search of her son. Groce was shot in the chest by police, leaving her permanently paralyzed from the waist down. See bell hooks, Yearning: Race, Gender, and Cultural Politics (Boston: South End Press, 1990); Rahul Gairola, "A Critique of Thatcherism and the Queering of Home in Sammy and Rosie Get Laid," South Asian Review 32, no. 3 (2011): 123-137.

36. Salman Rushdie argues in Imaginary Homelands that the experiences of racialized, working-class immigrants in Britain are rooted in the long history of British colonialism: "In short, if we want to understand British racism...it's impossible to even begin to grasp the nature of the beast unless we accept its historical roots. Four hundred years of conquest and looting, four centuries of being told you were superior to the Fuzzy-Wuzzies and the wogs, leave their stain." See Salman Rushdie, "The New Empire Within Britain" in Imaginary Homelands: Essays and Criticism 19811991 (London: Granta Books, 1991), 130.

37. In its focus on the residues of colonialism, Sammy and Rosie Get Laid is an important rejoinder to what Rushdie refers to as the "Raj revival"-the elaborate, nostalgic period representations of empire that dominated British cinema and television at the time, such as Richard Attenborough's Gandhi, David Lean's adaptation of $A$ Passage to India and the television production of Paul Scott's The Jewel in the Crown. See Rushdie, Imaginary Homelands.

38. For more on queer diasporic critique, see Gayatri Gopinath, Impossible Desires: Queer Diasporas and South Asian Public Cultures (Durham: Duke University Press, 2005).

39. This is not at all to undermine the fact that Rani has a rather scathing, critical wit. For instance, she describes heterosexual sex as "You know, that stuff when the woman spends the whole time trying to come, but can't. And the man spends the whole time trying to stop himself coming, but can't." This line is made all the more memorable and hilarious by the great Meera Syal's performance as Rani.

40. Hanif Kureishi, Sammy and Rosie Get Laid: The Screenplay and the Screenwriter's Diary (New York: Penguin, 1988), 15.

41. Gairola, "A Critique of Thatcherism," 132.

42. Gairola, "A Critique of Thatcherism," 132.

43. As bell hooks notes, two scenes in particular illustrate the limits of Sammy and Rosie's liberalism. On the night of the rebellion, Sammy is reclined on his sofa with headphones blaring music that literally cut off the sound of the rebellion outside his window. He snorts a line of cocaine, takes a bite of his McDonald's hamburger and masturbates to a porn magazine in his lap. As hooks notes, he is more concerned with satisfying his desires than participating in the rebellion. Rosie also seems indifferent to the rebellion, as we see her walk seemingly unfazed past burning cars on the street on her way to meet an unnamed lover. See bell hooks, Yearning.

44. Spivak, "In Praise of Sammy and Rosie Get Laid," 83.

45. As Yael Maurer observes about the juxtaposition of Rani's confrontation with Rafi and the manifestation of the taxi driver ghost, "One transgression, that of the heteronormative order which both Rafi and Thatcher's regime champion, is followed by another, the transgression inherent in the very act of unveiling the past as lurid and gruesome." See Yael Maurer, "'Not English but Londoners': Hanif Kureishi's Sammy and Rosie Get Laid, The London Literary Journal 11, No. 1 (2014): 38. For more on queer affiliation see Hong and Ferguson's Strange Affinities and Gayatri Gopinath's Unruly Visions.

46. Avery F. Gordon, Ghostly Matters, 22. 
47. Frantz Fanon, The Wretched of the Earth, trans. Richard Philcox (New York: Grove Press, 2004). P

48. "Seething presence" is Avery Gordon's phrase used to describe the agency of haunting, even if that haunting has not (yet) materialized in the figure of the ghost. See Ghostly Matters, 8 . ?

49. Gordon, Ghostly Matters, 8. ?

50. Chatterjee, "An Explosion of Difference," 177.

51. Gordon, Ghostly Matters, 8. ?

52. Cathy Cohen, "Punks, Bulldaggers and Welfare Queens: The Radical Potential of Queer Politics?" GLQ 3, (1997): 437-465. ?

53. Lisa Lowe, The Intimacies of Four Continents (Durham: Duke University Press, 2015).

54. Hong and Ferguson, Strange Affinities, 18.

55. Vanita Reddy and Anantha Sudhakar, "Introduction: Feminist and Queer Afro-Asian Formations," The Scholar and Feminist Online 14.3 (2018). ?

56. Thenmozhi Soundararajan and Sharmin Hossain, "South Asians for Black Lives"; Black Women Radicals and the Asian American Feminist Collective, "Black and Asian-American Feminist Solidarities: A Reading List," April 30, 2020, https://www.blackwomenradicals.com/blogfeed/black-and-asian-feminist-solidarities-a-reading-list < https://www.blackwomenradicals.com/blog-feed/black-and-asian-feminist-solidarities-areading-list>. ?

\section{Author Information}

\section{Ashvin Kini}

Ashvin R. Kini (he/him) is assistant professor of English at Florida Atlantic University.

View all of Ashvin Kini's articles.

\section{Article details}

Ashvin Kini, "Political Blackness, British Cinema, and the Queer Politics of Memory," Lateral 9.2 (2020).

https://doi.org/10.25158/L9.2.6

This content is licensed under a Creative Commons Attribution-NonCommercial 4.0 International License. Copyright is retained by authors. 
Lateral is the peer-reviewed, open access journal of the Cultural Studies Association.

ISSN 2469-4053 